\title{
Screening of Hepatitis A and B Seropositivity among Turkish Healthcare Providers Admitted to Occupational Health Services
}

\author{
Melike Mercan Başpınar (i) \\ University of Health Sciences, Gaziosmanpașa Taksim Training and Research Hospital, \\ Department of Family Medicine \& Occupational Health and Safety Clinic, İstanbul, Turkey \\ Correspondence should be addressed to Melike Mercan Başpınar; drmelikemercan@gmail.com
}

Received 4 December 2021; Revised 29 January 2022; Accepted 31 January 2022; Published 21 February 2022

Academic Editor: Ozgur Kasapcopur

Copyright (c) 2022 Melike Mercan Başpınar. This is an open access article distributed under the Creative Commons Attribution License, which permits unrestricted use, distribution, and reproduction in any medium, provided the original work is properly cited.

\begin{abstract}
This study aimed to determine the protection rates against hepatitis A virus (HAV) and hepatitis B virus (HBV), among healthcare providers (HCPs). The occupational health service data of Gaziosmanpaşa Training and Research Hospital between January 2020 and December 2020 were evaluated for this retrospective observational study. Of the 1,722 participants aged $34.40 \pm 9.16$ years, 48.6\% $(n=861)$ were male, and 55.0\% $(n=975)$ were doctors and nurses. The anti-HBs seropositivity rate was $87.5 \%(n=1,501)$. None of the participants had anti-HCV antibodies. Twelve participants were HBsAg positive. A level of anti-HBs titer $\geq 10 \mathrm{mIU} /$ $\mathrm{mL}$ was maintained in $66.7 \%$ of the HCPs vaccinated in childhood, while $71.3 \%(n=1,263)$ of the participants had anti-HAV IgG. HAV vaccination needs were higher in the doctor and nurse groups than in the other groups (60.5\% and 39.5\%, respectively, $p=0.003)$. HBV protection was higher among HCPs in polyclinics/wards and surgery/intensive care units than in those working in the emergency department (odds ratio (OR): 2.099, 95\% confidence interval $(\mathrm{CI})=1.285-3.429 ;$ OR: $1.592,95 \%$ $\mathrm{CI}=1.037-2.443$, respectively). HAV protection was higher in HCPs aged 31-50 years and over 50 years than in those aged 18-30 years (OR: 2.046, 95\% CI = 1.647-2.541; OR: 3.615, 95\% CI $=2.164-6.037$, respectively). In this study, one out of every two HCPs aged 18-30 years admitted to the occupational health control services had not yet received the HAV vaccine. The low levels of HBV protection among HCPs in the emergency department highlight the need for occupational health screening and HBV vaccination for HCPs working in emergency services in hospitals.
\end{abstract}

\section{Introduction}

The term healthcare provider (HCP) refers to all paid and unpaid people serving in healthcare settings who have the potential for direct or indirect exposure to patients or infectious materials, including body substances; contaminated medical supplies, devices, and equipment; contaminated environmental surfaces; or contaminated air [1]. Hospitals are high-risk workplace areas [2], and vaccinations for hepatitis B virus (HBV), influenza, measles, rubella, mumps, meningococcal infections, varicella, and severe acute respiratory syndrome coronavirus 2 (SARS-CoV-2) are recommended for HCPs by the Centers of Disease Control and Prevention (CDC) [1]. The national HBV vaccination program in Turkey began in July 1998 as a part of the mandatory childhood vaccine schedule [3]. The immunological memory of HBV has been reported to remain intact for at least 30 years [4], and immunocompetent individuals who achieve anti-HBs titers of $\geq 10 \mathrm{mIU} / \mathrm{mL}$ are protected against infection [5]. Booster doses for HCPs who initially respond to the vaccine but show a decline in antibody levels over time have been considered unnecessary by some, but several countries administer booster doses to specific risk groups [6]. The Occupational Safety and Health Administration mandates that employers offer $\mathrm{HBV}$ vaccination to all employees who have occupational risk and make available postexposure prophylaxis following exposure [7].

Hepatitis A is another vaccine-preventable acute infectious disease. HCPs do not have a substantially increased risk of hepatitis A virus (HAV) infection through occupational 
exposure, and although HAV vaccination is not routinely recommended for HCPs in the United States by the CDC $[8,9]$, HAV transmission from patients to HCPs is possible with fecal incontinence, inadequate hand hygiene, and sharing food or beverages [8, 10]. In 2016, the Turkish Ministry of Health requested that childhood vaccines (HAV, $\mathrm{HBV}$, measles, mumps, rubella, varicella, conjugated pneumococcal, and polysaccharide meningococcal vaccines) should also be administered to eligible adults in high-risk groups, such as HCPs [11]. In addition, the HAV and HBV vaccine indications in the Turkish Viral Hepatitis Prevention and Control Program that came into force in 2018 in Turkey and the Adult Immunization Guideline 2019 have included all HCPs [3]. Therefore, occupational health screening programs for HCPs have become essential to identify individuals who require primary or booster vaccinations. Effective occupational health service programs are key to prevent exposure to infectious agents and subsequent infections [1]. Thus, employment examinations and periodic health visits for HCPs within the context of occupational health and safety screening have been implemented under the Occupational Health and Safety Law no. 6331 since 2012 in Turkey [12].

This study was performed using occupational health and safety clinical records obtained before HCPs' exposure to biological hazards as a fundamental part of the Gaziosmanpaşa Training and Research Hospital Occupational Health Surveillance Program. This study sought to evaluate $\mathrm{HAV}, \mathrm{HBV}$, and HCV seropositivity among HCPs in their first employment examination results and demonstrate the need for primary or booster vaccination in periodic health control services.

\section{Materials and Methods}

This retrospective observational study was conducted between January 01, 2020, and December 30, 2020, among 1722 HCPs who were screened for employment examinations and routine periodic occupational health visits at Gaziosmanpaşa Training and Research Hospital in Istanbul, Turkey. Exclusion criteria included the use of immunosuppressive medications, renal failure requiring dialysis, hematopoietic cell or solid organ transplantation, cancer treatment, and known immunodeficiency. Medical records were requested from the hospital, and all the available records were reviewed. One thousand seven hundred twenty-two personal records with full serology results were included in this study with the permission of hospital management. The Clinical Research Ethics Committee of Gaziosmanpaşa Training and Research Hospital approved the study protocol on 23/09/2020 (approval no. 168). The approval included a waiver of the requirement to obtain informed consent.

The outcome variables were seropositivity for HAV, $\mathrm{HBV}$, and $\mathrm{HCV}$, antibody statuses, and vaccine requirements. Serological markers were detected by the enzymelinked immunosorbent assay (ELISA) (AxSYM Abbott, ARCHITECT i2000; Abbott, USA). Serum HBsAg, anti-HBs antibody, anti-HCV antibody, and anti-HAV IgG and IgM titers were recorded. Absence of $\mathrm{HBsAg}$ or anti-HBc and anti-HBs antibody levels of $0-10 \mathrm{mIU} / \mathrm{mL}$ for $\mathrm{HBV}$, absence of anti-HCV antibodies for HCV, and absence of anti-IgG/ IgM for HAV were considered to indicate seronegativity. Participants showing these findings were included in the vaccine program for the subsequent meeting during routine periodical health screening. In the control meeting of the dated sixth month, antibody titers and primary or booster vaccination status were screened again.

Normality was checked using the Kolmogorov-Smirnov test. Data were presented as mean, standard deviation, median, 25th and 75th percentiles, frequency, and percentage. Differences in variables between the two groups were analyzed using the Mann-Whitney $U$ test. Variables with three or more categories were compared using Kruskal-Wallis one-way analysis of variance. Multiple comparisons were performed using Dunn's test. Nominal variables were evaluated using the chi-square and Fisher's exact probability tests. The final model for independent predictors of anti-HBs and anti-HAV seropositivity was developed using binary logistic regression analysis. Statistical significance was set at $p<0.05$. Analyses were performed using NCSS 10 (2015, Kaysville, UT, USA).

\section{Results}

This study included 1722 participants (age: $34.40 \pm 9.16$ years; male/female: 911/861), including 975 (55.0\%) doctor/ nurse HCPs and 797 (45.0\%) other HCPs. Among the individuals, 221 (12.5\%) were HBV nonimmune (anti-HBs, 0-10 mIU/mL), $420(23.7 \%)$ were relatively immune (antiHBs, $10-99 \mathrm{mIU} / \mathrm{mL})$, and 1131 (63.8\%) were completely immune (anti-HBs, $\geq 100 \mathrm{mIU} / \mathrm{mL}$ ). HBsAg was detected in 12 HCPs. All HCPs showed negative results for anti-HCV antibodies. The HCPs were divided into three age groups (18-30, 31-50, and $>50$ years) and four primary departments (emergency, polyclinics/wards, surgery or intensive care units, and other departments). The distribution of health professions and working departments is shown in Figures 1 and 2. Among the 126 (7.1\%) HCPs who received childhood HBV vaccination (born 1998 and later), 84 (66.7\%) showed anti-HBs seropositivity, and 54 (42.9\%) were completely immune. However, 42 (33.3\%) participants were nonimmune and required booster vaccination.

Table 1 indicates that the $\mathrm{HBV}$ nonimmunization rate was significantly higher among males than females $(55.7 \%$ and $45.3 \%$, respectively, $p=0.025$ ), and $\mathrm{HBV}$ vaccination needs were more frequent among the nondoctor/-nurse HCPs than the doctor/nurse HCPs $(68.3 \%$ and $31.7 \%$, respectively, $p \leq 0.001)$. The higher HBV nonimmunization rate $(24 \%)$ versus protection rate $(16.1 \%)$ among hospital departments was significant for the emergency department $(p=0.004)$. One out of every six HCPs $(53 / 303)$ working in the emergency room was anti-HBs negative and required $\mathrm{HBV}$ vaccination. Analyses of the serum anti-HAV IgG antibody titers showed that $28.7 \%(n=509)$ of the participants were seronegative, and $71.3 \%(n=1263)$ were seropositive, although none of the participants had a history of HAV vaccination. As seen in Table 1, anti-HAV 


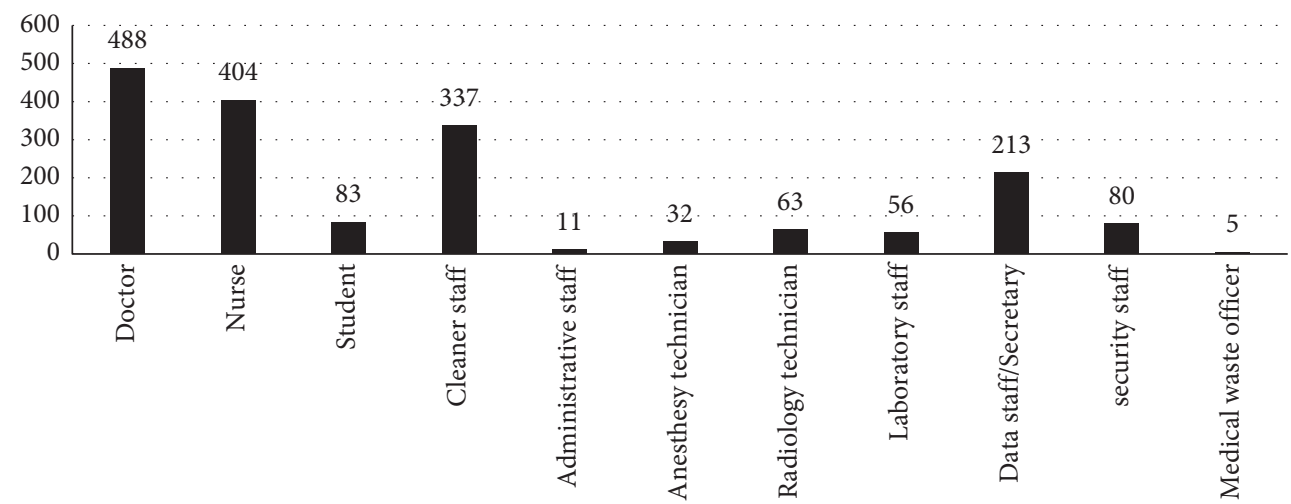

FIGURE 1: Distribution of health professions in employment examinations based on occupational health screening outcomes of the hospital in 2020 .

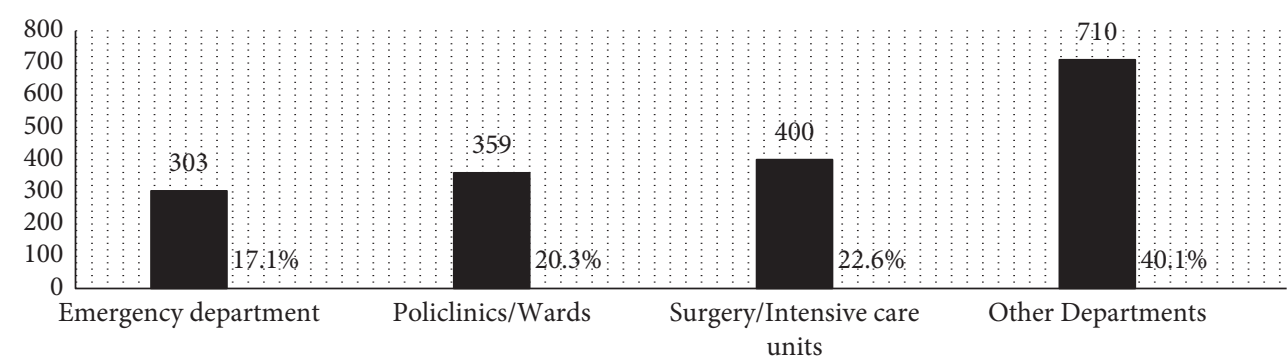

FIgURE 2: Distribution of working departments in employment examinations based on occupational health screening outcomes of the hospital in 2020.

TABLE 1: Comparison of the preliminary screening antibody seroprotection results of health professionals on the basis of sex, age, occupation, and primary departments.

\begin{tabular}{|c|c|c|c|c|c|c|c|}
\hline \multirow[b]{2}{*}{ Variables } & \multicolumn{3}{|c|}{$\begin{array}{l}\text { Anti-HBs antibody titer at preliminary screening } \\
\qquad(n=1722)\end{array}$} & \multirow[b]{2}{*}{$p$ value } & \multicolumn{2}{|c|}{$\begin{array}{l}\text { Anti-HAV IgG antibody titer at } \\
\text { preliminary screening }(n=1722)\end{array}$} & \multirow[b]{2}{*}{$p$ value } \\
\hline & & $\begin{array}{c}\text { Anti-HBs } \\
\text { seronegativity } \\
(<10 \mathrm{mIU} / \mathrm{mL}), n \\
(\%)\end{array}$ & $\begin{array}{c}\text { Anti-HBs } \\
\text { seropositivity } \\
(\geq 10 \mathrm{mIU} / \mathrm{mL}), n \\
(\%)\end{array}$ & & $\begin{array}{c}\text { Anti-HAV } \\
\text { seropositivity, } n \\
(\%)\end{array}$ & $\begin{array}{c}\text { Anti-HAV } \\
\text { seronegativity, } n \\
(\%)\end{array}$ & \\
\hline \multirow{2}{*}{ Sex } & $\mathrm{M}$ & $123(55.7 \%)$ & $738(47.6 \%)$ & \multirow{2}{*}{$\begin{array}{c}X^{2}=5.048 \\
p=0.025\end{array}$} & $642(50.8 \%)$ & 219 & \multirow{2}{*}{$\begin{array}{c}X^{2}=8.849 \\
p=0.003\end{array}$} \\
\hline & Female & $98(44.3 \%)$ & $813(52.4 \%)$ & & $621(49.2 \%)$ & $290(57.0 \%)$ & \\
\hline Age & $\begin{array}{c}18-30 \text { years } \\
31-50 \text { years } \\
>50 \text { years }\end{array}$ & $\begin{array}{c}95(43 \%) \\
117(52.9 \%) \\
9(4.1 \%) \\
\end{array}$ & $\begin{array}{c}619(39.9 \%) \\
816(52.6 \%) \\
116(7.5 \%) \\
\end{array}$ & $\begin{array}{c}X^{2}=3.641 \\
p=0.162\end{array}$ & $\begin{array}{c}437(34.6 \%) \\
720(57.0 \%) \\
106(8.4 \%) \\
\end{array}$ & $\begin{array}{c}277(54.4 \%) \\
213(41.8 \%) \\
19(3.7 \%) \\
\end{array}$ & $\begin{array}{c}X^{2}=62.375 \\
p \leq 0.001\end{array}$ \\
\hline \multirow{2}{*}{$\begin{array}{l}\text { Health } \\
\text { profession area }\end{array}$} & Doctor/nurse & $70(31.7 \%)$ & $905(58.3 \%)$ & \multirow{2}{*}{$\begin{aligned} X^{2} & =55.619 \\
p & \leq 0.001\end{aligned}$} & $667(52.8 \%)$ & $308(60.5 \%)$ & \multirow{2}{*}{$\begin{array}{c}X^{2}=8.692 \\
p=0.003\end{array}$} \\
\hline & $\begin{array}{l}\text { Other health } \\
\text { professionals }\end{array}$ & $151(68.3 \%)$ & $646(41.7 \%)$ & & $596(47.2 \%)$ & $201(39.5 \%)$ & \\
\hline \multirow{4}{*}{$\begin{array}{l}\text { Work } \\
\text { department in } \\
\text { the hospital }\end{array}$} & Emergency & $53(24 \%)$ & $250(16.1 \%)$ & \multirow{4}{*}{$\begin{aligned} X^{2} & =13.346 \\
p & =0.004\end{aligned}$} & $214(16.9 \%)$ & $89(17.5 \%)$ & \multirow{4}{*}{$\begin{array}{c}X^{2}=0.758 \\
p=0.860\end{array}$} \\
\hline & $\begin{array}{l}\text { Polyclinics/ } \\
\text { wards }\end{array}$ & $29(13.1 \%)$ & $330(21.3 \%)$ & & $262(20.7 \%)$ & $97(19.1 \%)$ & \\
\hline & $\begin{array}{c}\text { Surgery units/ } \\
\text { intensive care } \\
\text { units }\end{array}$ & $50(22.6 \%)$ & $350(22.6 \%)$ & & $286(22.6 \%)$ & $114(22.4 \%)$ & \\
\hline & Others & $89(40.3 \%)$ & $621(40.0 \%)$ & & $501(39.75)$ & $209(41.1 \%)$ & \\
\hline
\end{tabular}

seropositivity was significantly higher in men than in women (50.8\% and $49.2 \%$, respectively, $p=0.003$, respectively). Anti-HAV seropositivity was found more frequently in individuals aged $31-50$ than in other age groups $(p \leq 0.001)$. Moreover, $54.4 \%$ of HCPs aged $18-30$ years were in the anti-
HAV seronegative group and were required to be included in the HAV vaccination program. HAV vaccination needs were higher in the doctor/nurse group than in the nondoctor/-nurse group $(60.5 \%$ and $39.5 \%$, respectively, $p=0.003)$. 
TABLE 2: Comparison of anti-HBs antibody titers ( $\mathrm{mIU} / \mathrm{mL})$ according to HAV serology, health profession area, and working department in the hospital.

\begin{tabular}{|c|c|c|c|c|}
\hline \multirow{2}{*}{ Variables } & & \multicolumn{3}{|c|}{ Anti-HBs antibody titer $(\mathrm{mIU} / \mathrm{ml})$} \\
\hline & & Median & 25th and 75th percentiles & $p$ value \\
\hline \multirow[t]{3}{*}{ Age group } & ${ }^{1} 18-30$ years & 262 & $49-1000$ & \multirow{3}{*}{$\begin{array}{c}X^{2}=8.391 \\
p=0.015 \\
{ }^{2-1} p=0.017 \\
{ }^{2-3} p=0.033\end{array}$} \\
\hline & ${ }^{2} 31-50$ years & 179 & $37-816$ & \\
\hline & ${ }^{3}>50$ years & 255 & $60-1000$ & \\
\hline \multirow{2}{*}{ Sex } & Male & 188 & $34-888$ & \multirow{2}{*}{$\begin{array}{c}Z=-2.680 \\
p=0.007\end{array}$} \\
\hline & Female & 256 & $50-1000$ & \\
\hline \multirow{2}{*}{ Anti-HAV serology } & First anti-HAV seropositivity & 200 & $34-921$ & \multirow{2}{*}{$\begin{array}{c}Z=-2.641 \\
p=0.008\end{array}$} \\
\hline & First anti-HAV seronegativity & 260 & $64-1000$ & \\
\hline \multirow{2}{*}{ Health profession area } & Doctor/nurse & 325 & $73-1000$ & \multirow{2}{*}{$\begin{array}{c}Z=-8,050 \\
p \leq 0.001\end{array}$} \\
\hline & Nondoctor/-nurse & 141 & $20-587$ & \\
\hline \multirow{4}{*}{ Work department in the hospital } & ${ }^{1}$ Emergency & 161 & $22-733$ & \multirow{4}{*}{$\begin{aligned} X^{2} & =11.905 \\
p & =0.008 \\
1-2 & =0.033 \\
1-3 & =0.001 \\
{ }^{3-4} p & =0.028\end{aligned}$} \\
\hline & ${ }^{2}$ Polyclinics/wards & 215 & $50-949$ & \\
\hline & ${ }^{3}$ Surgery units/intensive care units & 295 & $50-1000$ & \\
\hline & ${ }^{4}$ Other departments & 209 & $42-899$ & \\
\hline
\end{tabular}

Table 2 shows that HCPs in the emergency department had the lowest anti-HBs antibody titers $(p=0.008)$ among all departments. In addition, anti-HBs antibody titers in HCPs in the emergency department (median =160) were lower than those in HCPs in polyclinics/wards and surgery/intensive care units (median $=215$ and 295 and $p=0.033$ and 0.001 , respectively).

Table 3 shows a comparison of the serological control findings for the doctor/nurse group versus the other HCPs. The nonvaccination rate in the doctor/nurse group versus the nondoctor/-nurse HCPs was significantly more frequent for HAV vaccines $(p \leq 0.001)$ and less frequent for $\mathrm{HBV}$ vaccines $(p \leq 0.001)$.

Table 4 evaluates the variables of total anti-HAV seropositivity and anti-HBs seropositivity. Total anti-HBs seropositivity was found to be 2.1 times higher in polyclinics/ wards, 1.6 times higher in the surgery/intensive care unit, and 1.7 times higher in other departments than in those working in the emergency department (OR: 2.099, 95\% $\mathrm{CI}=1.285-3.429$; OR: $1.59295 \% \mathrm{CI}=1.037-2.443$; OR: $1.748,95 \% \mathrm{CI}=1.194-2.558$, respectively). Total anti-HAV seropositivity was 2.1 times higher in participants aged 31-50 years and 3.6 times higher in those aged over 50 years versus those aged 18-30 years (OR: 2.046, 95\% $\mathrm{CI}=1.647-2.541$; OR: $3.615,95 \% \mathrm{CI}=2.164-6.037$, respectively). Total anti-HAV seropositivity was found to be 1.3 times higher in men than in women (OR: 1.277, 95\% $\mathrm{CI}=1.033-1,580)$. Nondoctor/-nurse HCPs had a higher anti-HAV seropositivity (OR: $1.277,95 \% \mathrm{CI}=1.028-1.585$ ) and a lower anti-HBs seropositivity (OR: 0.338, 95\% $\mathrm{CI}=0.249-0.461)$ than the doctor/nurse group.

\section{Discussion}

The occupational health and safety clinical records of 1722 HCPs at a tertiary hospital were included in this seroprevalence study. Most of the HCPs (87.5\%) were anti-
HBs-positive, while $63.8 \%$ were completely immune and had no need for booster HBV vaccination. Protective antiHBs concentration $(\geq 10 \mathrm{mIU} / \mathrm{mL})$ was maintained in $66.7 \%$ of the HCPs vaccinated in the childhood primary vaccination schedule. Anti-HAV seropositivity was $71.3 \%$, and HAV vaccine indication was detected in one out of every two HCPs aged 18-30 years. None of the participants showed anti-HCV positivity.

Good persistence of protective anti-HBs titers for up to 30 years with a primary vaccination without a booster dose has been demonstrated in HCPs exposed to occupational risk if their titer was initially higher than $100 \mathrm{mIU} / \mathrm{mL}$ [4]. On the contrary, according to the recommendations of the Advisory Committee on Immunization Practices (ACIP) and the European Consensus Group, HBV-vaccinated HCPs with documented immunity (anti-HBs concentrations $\geq 10 \mathrm{mIU} /$ $\mathrm{mL}$ ) require no postexposure prophylaxis, serological testing, or additional vaccination [5]. In a recent study at the Public Institution Health Centre of Sarajevo Canton, control measurements of protective anti-HBs titers of $\geq 10 \mathrm{mIU} / \mathrm{mL}$ among HCPs who received primary vaccination ten years previously showed a $74.3 \%$ seropositivity rate and a $25.7 \%$ need for booster dose [13]. While anti-HBs positivity with the vaccine was $26.4 \%$ in 1998 in Turkey, it increased to $86.9 \%$ in 2012 after the addition of the HBV vaccine to the childhood vaccination schedule [14]. The total HBV vaccination rate in this study was $12.5 \%(n=126)$. While $66.7 \%$ of the HCPs who received primary childhood $\mathrm{HBV}$ vaccination retained $\mathrm{HBV}$ protection without a booster vaccine, an additional dose of the HBV vaccine was required in $33.3 \%$. This protection rate highlights the contribution of Turkey's extended childhood vaccination program to the occupational health screening results. In a study conducted in Iran, HBV vaccine was required in 67/104 (64.4\%) of the students immunized at birth [15]. This difference might be due to different types of hepatitis $B$ vaccines in countries or other factors influencing vaccine effectiveness, such as cold-chain control systems. 
TABLE 3: Comparison of the periodic control screening immunization results of the doctor/nurse group with those of other health professionals in the hospital.

\begin{tabular}{|c|c|c|c|c|}
\hline Variables & & $\begin{array}{c}\text { Doctor/nurse } \\
(n=975), n(\%)\end{array}$ & $\begin{array}{l}\text { Nondoctor/-nurse } \\
(n=797), n(\%)\end{array}$ & $p$ value \\
\hline \multirow{4}{*}{$\begin{array}{l}\text { HBV immunization control in } \\
\text { periodic screening }\end{array}$} & $\begin{array}{l}\text { HBV vaccinated for control } \\
\text { screening }\end{array}$ & $70(29.9 \%)$ & $164(70.1 \%)$ & \multirow{4}{*}{$\begin{array}{c}X^{2}=111.854 \\
p \leq 0.001\end{array}$} \\
\hline & $\begin{array}{l}\text { HBV nonvaccinated for control } \\
\text { screening }\end{array}$ & $22(25.9 \%)$ & $63(74.1 \%)$ & \\
\hline & Protective anti-HBsAg titer & $879(61.0 \%)$ & $562(39.0 \%)$ & \\
\hline & $\begin{array}{l}\text { HBsAg positive members in } \\
\text { follow }\end{array}$ & $4(33.3 \%)$ & $8(66.7 \%)$ & \\
\hline \multirow{3}{*}{$\begin{array}{l}\mathrm{HAV} \text { immunization control in } \\
\text { periodic screening }\end{array}$} & $\begin{array}{l}\text { HAV vaccinated for control } \\
\text { screening }\end{array}$ & $130(52.6 \%)$ & $117(47.4 \%)$ & \multirow{3}{*}{$\begin{aligned} X^{2} & =19.048 \\
p & \leq 0.001\end{aligned}$} \\
\hline & $\begin{array}{l}\text { HAV nonvaccinated for control } \\
\text { screening }\end{array}$ & $179(67.3 \%)$ & $87(32.7 \%)$ & \\
\hline & Protective antibody for HAV & $666(52.9 \%)$ & $593(47.1 \%)$ & \\
\hline
\end{tabular}

TABLE 4: Bivariate analysis of the association between participant characteristics and total anti-HAV seropositivity and anti-HBs seropositivity among healthcare providers.

\begin{tabular}{|c|c|c|c|c|c|}
\hline Variables & & $\begin{array}{l}\text { Anti-HBs seropositivity Adj. } \\
\text { OR }^{\mathrm{a}}(95 \% \mathrm{CI})\end{array}$ & $p$ & $\begin{array}{l}\text { Total anti-HAV seropositivity Adj. } \\
\text { OR }^{\mathrm{b}}(95 \% \mathrm{CI})\end{array}$ & $p$ \\
\hline Sex & $\begin{array}{l}\text { Female } \\
\text { Male }\end{array}$ & $\begin{array}{c}\text { Ref } \\
0.789(0.590-1.054) \\
\end{array}$ & 0.109 & $\begin{array}{c}\text { Ref } \\
1.277(1.033-1.580) \\
\end{array}$ & 0.024 \\
\hline Age group (years) & $\begin{array}{c}18-30 \\
31-50 \\
>50\end{array}$ & $\begin{array}{l}- \\
- \\
-\end{array}$ & $\begin{array}{l}- \\
- \\
-\end{array}$ & $\begin{array}{c}\text { Ref } \\
2.046(1.647-2.541) \\
3.615(2.164-6.037)\end{array}$ & $\begin{array}{l}\leq 0.001 \\
\leq 0.001\end{array}$ \\
\hline Health profession & $\begin{array}{c}\text { Doctor/nurse } \\
\text { Nondoctor/-nurse }\end{array}$ & $\begin{array}{c}\text { Ref } \\
0.338(0.249-0.461) \\
\end{array}$ & $\leq 0.001$ & $\begin{array}{c}\text { Ref } \\
1.277(1.028-1.585) \\
\end{array}$ & 0.027 \\
\hline $\begin{array}{l}\text { Work department in the } \\
\text { hospital }\end{array}$ & $\begin{array}{c}\text { Emergency } \\
\text { Polyclinics/wards } \\
\text { Surgery units/intensive } \\
\text { care units } \\
\text { Other departments }\end{array}$ & $\begin{array}{c}\text { Ref } \\
2.099(1.285-3.429) \\
1.592(1.037-2.443) \\
1.748(1.194-2.558)\end{array}$ & $\begin{array}{l}0.003 \\
0.033 \\
0.004\end{array}$ & $\begin{array}{l}- \\
- \\
-\end{array}$ & \\
\hline
\end{tabular}

${ }^{a}$ Adjusted according to sex, health profession, and work department in the hospital. ${ }^{b}$ Adjusted according to sex, age group, and health profession in the hospital.

In this study, the anti-HBs seropositivity rate was $87.5 \%$, similar to the findings in recent studies conducted on HCPs in Turkey in which anti-HBs seropositivity was found in $87.5 \%$ of dental faculty students/staff [16], 89.4\% of nursing students [17], and $93.7 \%$ of medical faculty students [18]. The $\mathrm{HBV}$ vaccination requirement rate was $12.5 \%$. Obiri-Yeboah et al. showed an HBV vaccination requirement rate of $8.2 \%$ for HCPs in public hospitals in Ghana [19] and found differences among occupations [19]. Costa et al. observed immunity in $25.8 \%$ of the workers vaccinated for HBV and found a lower prevalence among contract workers [20]. In this study, doctors and nurses had less need for HBV vaccination than other HCPs. Additionally, the need for HBV vaccination in emergency medical services was higher than that in other departments. A systematic review suggested that emergency medical service providers are at an increased risk of contracting hepatitis B [21]. Therefore, it is not difficult to predict a high probability of transmission when dealing with critically ill patients in the resuscitation room [22]. In the present study, the number of staff with seronegativity was significantly higher than that with seropositivity. So, the emergency medical service department would benefit most from occupational disease screening in HCPs.

Grzeszczuk et al. found that the frequency of antiHAV antibodies among Polish HCPs was $71.4 \%$, and individuals older than 40 years were anti-HAV positive more frequently than younger individuals [23]. Erramuspe et al. found that HCPs aged under 41 years in Cordoba showed a statistically significant association with 3.57 -fold higher seronegativity with a $62.2 \%$ rate of antiHAV seropositivity [24]. HAV infection has intermediate endemicity in Turkey [25]. In a recent Turkish study, total anti-HAV seropositivity was found to be 1.73 times higher in HCPs $\geq 21$ years old [18]. Older age has been shown to be an important factor influencing a higher rate of antiHAV seropositivity. HCPs aged over 50 years and between 31 and 50 years had 3.6- and 2-fold higher seropositivity than those aged 18-30 years. In a study conducted with employees of a public hospital in Istanbul, anti-HAV seropositivity was significantly higher in participants aged 35 years and older than in those under 35 years of age [26]. In another study conducted with 1112 adults in Rize 
province, the anti-HAV seropositivity rate was $92 \%$ in people over 50 years of age [27]. In a study performed by Meryem et al., $100 \%$ anti-HAV seropositivity rate was shown in the participants aged 50 years and over, and the seropositivity rate increased with age [28]. A novel study conducted among students and staff in the dental faculty showed $31.3 \%$ anti-HAV seropositivity [16]. In different studies in Turkey, anti-HAV seropositivity among HCPs showed a broad range: $10.17 \%$ [29], 27.3\% [30], 15\% [31], $34.9 \%$ [18], and $64.49 \%$ [26]. In the present study, approximately three out of four HCPs $(71.3 \%)$ were immune to $\mathrm{HAV}$ without showing an $\mathrm{HAV}$ vaccination history. However, one out of every two HCPs aged 18-30 years who underwent the employment examination had an $\mathrm{HAV}$ vaccine indication, especially for doctors or nurses among HCPs. In the future, childhood HAV vaccination may promote HAV protection in individuals aged 18-30 years, but Mosites et al. showed that the predicted seropositivity rate was $55.3 \%$ at 25 years, $49.8 \%$ at 30 years, and $45.7 \%$ at 35 years of age in a study on the immunogenicity of the hepatitis A vaccine 20 years [32]. Therefore, since the protection of childhood vaccines will decrease until the age of 30 years, it is important to determine the need for HAV vaccines in individuals aged 18-30 years.

Anti-HCV was not detected in this study population, similar to the findings of studies in Turkey $[17,31]$. However, anti-HCV positivity was between $0.4 \%$ and $1.5 \%$ in community-based studies in Turkey and $1 \%-2.4 \%$ among HCPs [33]. Although needlesticks and contact with blood and body fluids are daily workplace risks in hospitals, the risk of HCV transmission among HCPs in Italy was found to be only $0.31 \%$ after percutaneous exposure to a hollow-bore, bloodfilled needle, suggesting that HCPs may not be at high risk because of the use of needlestick prevention devices and other protective equipment [34]. Globally, injection drug use is the primary risk factor for HCV infection [35]. Therefore, we believe that the anti-HCV seronegativity in this study may be attributed to the HCV awareness of HCPs and their appropriate implementation of preventive measures, such as the use of disposable medical devices.

The main limitation of this study was the lack of data related to personal features and behavior (prior number of HBV vaccination doses for HCPs who were born before 1998, sexual behavior, hygiene habits, nicotine dependence level, alcohol consumption, and so on), which may have explained or confused the protection rates. Second, this study did not include any data to explain the high anti-HAV positivity rate without HAV vaccination, except for older age. A case-control study in India reported a significant association between HAV and a 120-fold higher risk related to a history of exposure to food from a hotel, indicating the necessity of enforcing food safety rules [36]. Thus, fecal-oral transmission sources and the factors related to these sources (geography of childhood, sanitation awareness, food habits, hygiene in hospital toilets, cafeteria, immunization of cooking chefs and food handlers at workplaces, etc.) should be investigated in a future study.

In this study, the nonvaccinated control rate in the doctor and nurse group versus other HCPs was more frequent for $\mathrm{HAV}$ vaccination and less frequent for $\mathrm{HBV}$ vaccination. Unfortunately, the retrospective study plan precluded questions about factors such as vaccine hesitancy, vaccine knowledge, and attitude.

\section{Limitations}

Although the disappearance of circulating antibodies does not necessarily mean a loss of protection, the age at which the first dose of participants was given is unclear because it was questioned whether they were only vaccinated with a full dose and what time was the last dose. Depending on mandatory childhood HBV vaccination which was introduced in Turkey in 1998, 126 participants born after this date have been considered to have received the childhood HBV vaccine in this study population including 1722 participants. So, the age distribution factor was a confounding factor in evaluating the antibody titer. In addition, since the occupational health and safety services started to function in our hospital as of 2020, the participants' protection levels and vaccination needs were scanned with the anti-HBs titer. The childhood and adolescence records of the study sample could not be standardized since the digital vaccine registration system was not widespread before 2010 when the family medicine and vaccination system was spread to all countries.

\section{Conclusions}

This study demonstrated that one out of every two HCPs aged 18-30 years who was admitted to occupational health control services required HAV vaccination, and this trend was especially prominent among doctors and nurses. The lower levels of HBV protection in HCPs working in the emergency department versus other departments highlighted the importance of occupational health screenings and $\mathrm{HBV}$ vaccination programs in the emergency medicine services of public hospitals.

\section{Data Availability}

The data used to support the findings of this study are available upon request to the author.

\section{Conflicts of Interest}

The author declares that there are no conflicts of interest.

\section{Acknowledgments}

The author wishes to thank the nurse Çiğdem Polat at Gaziosmanpaşa Training and Research Hospital's Occupational Health and Safety Department for collecting records.

\section{References}

[1] E. S. Shenoy and D. J. Weber, "Occupational health update," Infectious Disease Clinics of North America, vol. 35, no. 3, pp. 717-734, 2021. 
[2] M. E. Alagüney, S. E. Atacan, K. Atli, N. Çalik Başaran, N. Başaran, and Ö Bİlek, "İş Sağlığı Ve Güvenliği Meslek Hastalıkları," 2020.

[3] Turkish Ministry of Health, "Viral hepatitis prevention and control program of Turkey," 2018, https://kms.kaysis.gov.tr/ (X(1)S(t2fx3bjfkw4034ljzk5borjk))/Home/Goster/144104? AspxAutoDetectCookieSupport $=1$.

[4] S. Cocchio, V. Baldo, A. Volpin et al., "Persistence of anti-Hbs after up to 30 years in health care workers vaccinated against hepatitis B virus," Vaccines, vol. 9, no. 4, p. 323, 2021.

[5] G. Dini, A. Toletone, I. Barberis et al., "Persistence of protective anti-HBs antibody levels and anamnestic response to HBV booster vaccination: a cross-sectional study among healthcare students 20 years following the universal immunization campaign in Italy," Human Vaccines \& Immunotherapeutics, vol. 13, no. 2, pp. 440-444, 2017.

[6] R. Durlach, S. Laugas, C. B. Freuler, V. E. Rodríguez, and M. Costa, "Ten-year persistence of antibody to hepatitis B surface antigen in healthcare workers vaccinated against hepatitis B virus, and response to booster vaccination," Infection Control \& Hospital Epidemiology, vol. 24, no. 10, pp. 773-776, 2003.

[7] S. Schillie, C. Vellozzi, A. Reingold et al., "Prevention of hepatitis B virus infection in the United States: recommendations of the advisory committee on immunization Practices," MMWR. Recommendations and Reports, vol. 67, no. 1, pp. 1-31, 2018.

[8] R. A. Goodman, "Nosocomial hepatitis A," Annals of Internal Medicine, vol. 103, no. 3, pp. 452-454, 1985.

[9] N. P. Nelson, R. Link-Gelles, M. G. Hofmeister et al., "Update: recommendations of the advisory committee on immunization practices for use of hepatitis A vaccine for postexposure prophylaxis and for preexposure prophylaxis for international travel," MMWR. Morbidity and Mortality Weekly Report, vol. 67, no. 43, pp. 1216-1220, 2018.

[10] N. P. Nelson, M. K. Weng, M. G. Hofmeister et al., "Prevention of hepatitis A virus infection in the United States: recommendations of the advisory committee on immunization practices," MMWR. Recommendations and Reports, vol. 69, no. 5, pp. 1-38, 2020.

[11] Risk grubu ve sağlık Çalışanı Aşılamaları, 2020, https://hsgm. saglik.gov.tr/depo/birimler/asi-onlenebilir-hast-db/saglik_ calisanlari_asilama/Risk_Grubu_ve_Saglik.pdf.

[12] 6331 İş sağlığı ve güvenliği Kanunu, 2020, https://www. resmigazete.gov.tr/eskiler/2012/06/20120630-1.htm.

[13] S. Šegalo, E. Kiseljaković, L. Berhamović, A. Pašalić, S. Mahmutović Vranić, and E. Berhamović, "Hepatitis B vaccination coverage rate and immune response among primary health care workers in Sarajevo Canton, Bosnia and Herzegovina," Microbes and Infection, vol. 2, pp. 60-67, 2021.

[14] The Epidemiology of Hepatitis C Virus Infection, 2013, https://www.klimik.org.tr/wp-content/uploads/2019/04/\% C3\%9Clkemizde-ve-D\%C3\%BCnyada-HepatitEpidemiyolojisi.pdf.

[15] A. Allami, N. Mohammadi, and A. Najar, "Immunization status against hepatitis B among Iranian junior medical, nursing, and obstetrics students with different vaccination patterns," Biotechnology and Health Sciences, vol. 2, Article ID e27156, 2015.

[16] R. Kutlu, A. Terlemez, N. Demirbaş, and A. E. Hatir, "Evaluation of hepatitis A and hepatitis B seroprevalence in dental faculty students and staff," Turkish Journal of Family Medicine and Primary Care, vol. 14, pp. 246-251, 2020.
[17] Z. Irmak, B. Ekinci, and A. F. Akgul, "Hepatitis B and C seropositivity among nursing students at a Turkish university," International Nursing Review, vol. 57, no. 3, pp. 365-369, 2010.

[18] A. Acikgoz, D. Cimrin, S. Kizildag, N. Esen, P. Balci, and A. A. Sayiner, "Hepatitis A, B and C seropositivity among first-year healthcare students in western Turkey: a seroprevalence study," BMC Infectious Diseases, vol. 20, no. 1, p. 529, 2020.

[19] D. Obiri-Yeboah, Y. A. Awuku, G. Adjei et al., "Post hepatitis $B$ vaccination sero-conversion among health care workers in the Cape Coast Metropolis of Ghana," PLoS One, vol. 14, no. 6, Article ID e0219148, 2019.

[20] F. M. d. Costa, A. M. E. d. B. L. Martins, C. d. A. Lima, Q. F. Rodrigues, K. K. F. Santos, and R. C. Ferreira, "Fatores associados à verificação da imunização pós-vacinação contra hepatite B entre trabalhadores da Atenção Primária," Cadernos Saúde Coletiva, vol. 25, no. 2, pp. 192-200, 2017.

[21] G. Rischitelli, J. Harris, L. McCauley, R. Gershon, and T. Guidotti, "The risk of acquiring hepatitis B or C among public safety workers," American Journal of Preventive Medicine, vol. 20, no. 4, pp. 299-306, 2001.

[22] T. C. Ozturk, O. Guneysel, A. Tali, S. E. Yildirim, O. E. Onur, and S. Yaylaci, "Hepatitis B, hepatitis C and HIV seroprevalence in critically ill emergency medicine department patients in a tertiary inner city hospital in Istanbul, Turkey," Pakistan journal of medical sciences, vol. 30, pp. 703-707, 2014.

[23] A. Grzeszczuk, E. Sokolewicz-Bobrowska, and S. Chlabicz, "Occupational risk of hepatitis A infection among health care providers in northeastern Poland," Medical Science Monitor: International Medical Journal of Experimental and Clinical Research, vol. 9, 2003.

[24] C. Erramuspe, M. Racca, V. Sotelo, and M. Demarchi, "Efecto de la edad en la seroprevalencia de anticuerpos IgG antivirus de hepatitis A en el personal de salud," Alergología e Inmunología Clínica, vol. 39, pp. 6-13, 2020.

[25] World Health Organization, "Hepatitis A," 2020, https:// www.who.int/en/news-room/fact-sheets/detail/hepatitis-a.

[26] F. C. C. Yagan, G. G. Olcum, and S. E. Cakar, "Hepatitis A seroprevalence in employees of a public hospital," Eurasian Journal of Medicine and Oncology, vol. 1, pp. 92-95, 2017.

[27] A. Ç Çiçek, O. Z. Sahin, M. K. Topaloglu, Y. I. H. Kazanci Aat, K. Sahin, and D. Z. U. Gündoğdu, "The seroprevalence of HBsAg, anti-HBs ve anti-HCV in patients applied hemodialysis in Rize Province," Viral Hepatit Dergisis, vol. 19, no. 1, 2013.

[28] I. Meryem, B. Gültepe, and M. Z. Doymaz, "Erişkin yaş gruplarında hepatit A seroprevalansı," Abant Tp Dergisi.vol. 4, pp. 54-58, 2015.

[29] Ş. Budak, "Evaluation of entry examination results of apprentices and interns made by workplace health and safety unit," Forbes Journal of Medicine, vol. 1, no. 1, pp. 5-10, 2020.

[30] A. Ergin, S. Uzun, A. Bozkurt et al., "Hepatitis A seroprevalence and contributing factors in the sixth year medical faculty students," TAF Preventive Medicine Bulletin, vol. 12, no. 6, pp. 625-632, 2013.

[31] Ç Kader, S. Yolcu, A. Erbay, N. K. Akça, S. Yüzer, and S. Polat, "Investigation of hepatitis-B and C seroprevelances in bozok university school of health students," Viral Hepatit Dergisis, vol. 19, no. 2, 2013. 
[32] E. Mosites, S. Seeman, S. Negus et al., "Immunogenicity of the hepatitis A vaccine 20 years after infant immunization," Vaccine, vol. 38, no. 32, pp. 4940-4943, 2020.

[33] N. Tozun, O. Ozdogan, Y. Cakaloglu et al., "Seroprevalence of hepatitis $\mathrm{B}$ and $\mathrm{C}$ virus infections and risk factors in Turkey: a fieldwork TURHEP study," Clinical Microbiology and Infections, vol. 21, no. 11, pp. 1020-1026, 2015.

[34] G. De Carli, V. Puro, and G. Ippolito, "Risk of hepatitis C virus transmission following percutaneous exposure in healthcare workers," Infection, vol. 31, pp. 22-27, 2003.

[35] S. Schillie, C. Wester, M. Osborne, L. Wesolowski, and A. B. Ryerson, "CDC recommendations for hepatitis C screening among adults-United States," MMWR. Recommendations and Reports, vol. 69, no. 2, pp. 1-17, 2020.

[36] P. S. Rakesh, T. T. C. R. Mainu, A. Raj et al., "Investigating a community wide outbreak of hepatitis A in Kerala, India," Journal of Family Medicine and Primary Care, vol. 7, pp. 1537-1541, 2018. 